when faced with the inevitable and perhaps unrealistic demands for professional care by traumatised and suffering survivors. The reason for this lack of cover may be a reflection of the working party's view, and indeed the main thrust of the report, that nursing as we know it today would be irrelevant and therefore discussion of ethical implications of the nurses' role is inappropriate.

Where the report falls down is in failing to draw conclusions from its findings about the implications of those findings for nurses, civil defence planning, and action for the RCN. In effect the findings are that there is no role for nursing care in the aftermath of a nuclear strike. It should presumably follow that there can therefore be no justification for the nursing profession being involved in civil defence planning for nuclear war. Moreover such involvement would falsely engender a sense of security in the community which in turn would influence attitudes to nuclear war and defence strategies. However, because of an apparent nervousness about the 'apolitical position of the nursing profession' and a wish to avoid the 'profound, ethical and political issues' the working party fails to draw this conclusion from its own devastating findings.

FIONA M ROSS Department of Nursing Studies, Chelsea College, University of London

\section{Medical Negligence}

J A Cameron. Edinburgh, The Law Society of Scotland, 1983. £2.25

Cases of medical negligence have increased greatly in recent years. $\mathrm{Mr}$ Cameron's text is therefore welcome as the first which is devoted exclusively to the subject. His commentary is relevant both north and south of the border as the substantive law is the same. The author is a senior member of the Scottish Bar with considerable experience in this area.

He begins by explaining that a higher standard of care is expected of medical men and how this conduct is to be judged. Reference is made to the classic exposition by Lord President Clyde in Hunter v Hanley and the author shows how this has become the accepted test in the United Kingdom. He then explains that a medical man is to be judged by the standards of others in the profession who are at the same level in their career. As he points out, however, no one guarantees success on every occasion, but he explains the danger of categoris- ing exceptions under the heading of 'errors of judgement,' a red herring invented by Lord Denning.

Having looked at the test for negligence and how the test is applied, Cameron turns his attention to related topics such as consent. Should the patient be told anything and, if so, what? How much should be said? These questions are looked at in the light of the reported cases. The other related issues are whether, and what, to tell the patient if something goes wrong, the need for doctors to keep up to date and the dangers of acting outwith their field of competence.

The concluding part of the book considers a miscellany of matters including res ipsa loquitur - when the doctor's conduct requires some explanation (for example the swab left in situ) - vicarious responsibility, contributory negligence and the assessment of damages.

The author's text is both clear and readable. I would strongly recommend it to medical practitioners and others who are interested in this area. It is a slim volume, but packed with useful material - ideal for the pocket, in respect of both size and price.

D J CUSINE

Faulty of Law, University of Aberdeen

\section{Medical Stewardship: Fulfilling the Hippocratic Legacy \\ M Oliver Kepler. Westport,}

Connecticut and London, Greenwood

Press, 1981. £28.95

This book is a statement of a code of practice both personal and corporate. The background of the author gives strong clues as to the motivation for writing it. Fourteen years after graduating in medicine, Dr Kepler felt he had to learn more if he wanted a fulfilling practice of medicine and so he followed a master of arts programme in religion. In addition to this dual qualification he has had very varied clinical experience and it is this breadth of outlook which entitles him to write what is not a textbook of medical ethics but rather a description of an approach to medical practice which reflects what he calls philia - brotherly or neighbourly love. He considers that love for one's neighbour is fundamental to his thesis of medical ethics.

The book starts with a valuable account of the origins of medical ethics from earliest times. It continues with a very interesting and outspoken case study of the American Medical Associa- tion and asks what are the proper ethical functions of a professional organisation. There follows a chapter on the ethics of market-place medical practice as compared with salaried service or insurance schemes. This is interesting but predictable and perhaps somewhat superficial. In his analysis of the ethics of professional competence the author touches on quality assurance, peer review and the responsibility of doctors to colleagues with impaired performance. On this same general theme $\mathrm{Dr}$ Kepler outlines a number of what he calls under-utilised roles of the doctoras priest, as advocate, as comforter and as steward. In this section he gives his views on euthanasia and on abortion but does not argue them very fully. Again, rather superficially, he touches on drug abuse and on clinical trials but the book is better when, as is its declared intention, it is dealing with general principles and an ideal way of professional life, than when it goes into individual examples.

We come back to general principles in the chapter entitled Philia among Health Professionals in which interaction with clergy, with other health professionals and with administrators is discussed. One of the most striking and original chapters is one in which doubt is cast on the ethics of the whole process of medical education as we now know it. We have an analysis of the behaviour of medical schools over the last quarter of a century with criticism of methods of selecting medical students (though the difficulties and some recent attempts at change are recognised), of curriculum content and of failure to instil proper attitudes towards practice. In spite of these later criticisms, the author has little faith in the effect of curriculum in improving the basic personality of a student and so he comes back to selection as the key factor, notwithstanding its difficulties.

The book is a very genuine personal testament of caring practice and the reader gets the benefit of the experience of a writer who, after practising medicine for some years, returns to university to study arts and religion. The chapters on the ethics of professional organisations and of medical education are the most stimulating and the book is worth reading for these alone. Otherwise there is not much that is original and although it is interesting its price in the United Kingdom makes it somewhat prohibitive to the private purchaser.

A S DUNCAN

Emeritus Professor of Medical Education, University of Edinburgh 